\title{
Pengaruh Pemberian Antibiotik Profilaksis Terhadap Infeksi Luka Operasi pada Pasien Bedah Obstetri dan Ginekologi di RSUP Dr. Sardjito
}

\author{
Effect of Prophylactic Antibiotics on Surgical Site Infections in Obstetric and Ginecology \\ Surgical Patients in RSUP Dr. Sardjito
}

\section{Mawaqit Makani, Tri Murti Andayani*}

Magister Farmasi Klinik, Fakultas Farmasi, Universitas Gadjah Mada, Corresponding author: Tri Murti Andayani: Email: trimurtia@yahoo.com

Submitted: 26-07-2019

Revised: 19-09-2019

Accepted: 19-09-2019

\begin{abstract}
ABSTRAK
Antibiotik profilaksis merupakan obat yang digunakan dalam pencegahan dan penanganan pada infeksi luka operasi (ILO). Infeksi luka operasi menjadi penyumbang infeksi sebesar $14 \%$ dan kejadian tertinggi berasal dari obstetri dan ginekologi. Tujuan dari penelitian adalah untuk mengetahui pengaruh kesesuaian dan prediksi kadar pada penggunaan antibiotik profilaksis terhadap kejadian infeksi luka operasi pada pasien yang bedah obsgin. Penelitian ini dilakukan secara observasional analitik dengan rancangan case control study. Data penelitian diambil dari rekam medik pasien bedah obsgin pada bulan Januari - Desember 2018 kemudian dikelompokkan menjadi kelompok ILO dan tidak ILO. Dilakukan evaluasi terhadap kesesuain jenis, dosis, waktu pemberian, interval, dan prediksi kadar antibiotik dalam darah pada kedua kelompok. Analisis data dilakukan uji chi-square dan Fisher exact test untuk data kategorikal untuk melihat profil baseline sampel dan hubungan antara kesesuaian antibiotik profilaksis dengan kejadian ILO. Hasil penelitian pada 21 kelompok ILO dan 63 kelompok tidak ILO tidak terdapat hubungan antara kesuaian antibiotik profilaksis dengan kejadian luka operasi $(p>0,05)$, prediksis kadar antibiotik saat selesai operasi memiliki hubungan yang bermakna terhadap kejadian ILO ( $p<0,01$; RR 4,5; 95\% CI 2,9-6,7). Kata kunci: Antibiotik Profilaksis; prediksi kadar; infeksi luka operasi; bedah obsgin
\end{abstract}

\section{ABSTRACT}

Prophylactic antibiotics are drugs used in prevention and treatment of surgical wound infection or surgical site infection (SSI). Surgical site infections contribute $14 \%$ of infections and the gihest incidence is from obstetrics and gynecology. The aim of the study to determine the effect of the suitability and prediction of levels on the use of prophylactic antibiotics on the incidence of surgical site infections in obgyn surgical patients. This study was conducted by analytic observational with a case control study design. The research data was taken from the medical records of obsgin surgical patients in January - December 2018 then grouped into SSI and non-SSI groups. An evaluation of the suitability of type, dose, time of administration, interval, and prediction of antibiotic levels in the blood in both groups. Data analysis was performed by chi-square test and Fisher's exact test for categorical data to see the sample baseline profile and the relationship between the suitability of prophylactic antibiotics and the incidence of the SSI. The results of the study on 21 SSI groups and 63 non-SSI groups did not have a relationship between prophylactic antibiotic fit and the incidence of surgical injuries ( $p>0.05)$, prediction of antibiotic levels at completion of surgery had a significant association with SSI events ( $\mathrm{p}<0.01$; RR 4.5; 95\% CI 2.9-6.7).

Keyword: Antibiotic prophylaxis; level prediction; surgical site infection; surgical obsgin

\section{PENDAHULUAN}

Di negara berpenghasilan tinggi, tingkat ILO pada operasi ginekologi sama dengan prosedur bedah lainnya. Histerektomi pada ginekologi memiliki tingkat kejadian ILO 1,7\% menurut CDC (2014). Sedangkan pada persalinan sesar dilaporkan 3\% - 15\% mengalami ILO di Amerika Serikat. Berdasarkan

laporan surveilans Pencegahan dan
Pengendalian Infeksi (PPI) RSUP Dr Sardjito angka kejadian infeksi karena operasi tahun 2017 sebanyak 0,10\% pada operasi bersih, $1,16 \%$ pada operasi bersih terkontaminasi dan operasi kotor dengan kejadian terbanyak adalah dari obstetri dan ginekologi yaitu 1,27\%. Kejadian infeksi luka operasi tidak terlepas dari 
faktor risiko yang mengikutinya. Berdasarkan (Bharatnur dan Agarwal, 2018) terdapat beberapa faktor yang mempengaruhi terjadinya infeksi luka operasi yaitu faktor pasien sepert usia, diabetes, hipoalbumin, length of preoperative stay, skor ASA (American Society of Anesthesiologists); faktor pembedahan seperti jenis operasi, durasi, sifat operasi; dan antibiotik profilaksis.

Berdasarkan rekomendasi IDSA (Infection Disease Society of America), pemberian antibiotik profilaksis sebaiknya diberikan pada rentang 60 menit sebelum insisi dan diberikan dengan interval yang sesuai dengan waktu paruhnya (Bratzler dkk., 2013). Berdasarkan penelitian (Koch dkk., 2013) yang melakukan analisis pada 4400 tindakan bedah sejak tahun 2006 sampai 2012, terdapat 4239 pasien $(95,1 \%)$ mendapatkan terapi antibiotik profilaksis dengan durasi satu jam menjelang insisi. Kejadian infeksi pasca operasi terjadi pada 444 pasien $(10 \%)$ pada kasus ini. Pemberian antibiotik 30 menit sebelum insisi pada 3140 pasien terjadi infeksi sebanyak 283 pasien (9\%). Sedangkan dari 1099 pasien dengan pemberian antibiotik antara 60 sampai 30 menit sebelum insisi terjadi infeksi sebanyak $11,7 \%$ dengan $\mathrm{p}=0,01$. Dua ratus empat belas pasien yang mendapatkan antibiotik profilaksis lebih dari 60 menit terjadi infeksi sebanyak 14,5\% (Koch dkk., 2013).

Antibiotik profilaksis yang adekuat merupakan hal yang penting dalam upaya pencegahan infeksi luka operasi. Untuk memperoleh efek yang adekuat, antibiotik harus tetap berada pada tempat ikatannya untuk waktu yang cukup memadai. Kadar hambat minimum (KHM) merupakan gambaran jumlah minimal obat yang diperlukan untuk menghambat pertumbuhan bakteri (Elkomy dkk., 2014).

Tujuan dilakukan penelitian adalah untuk mengetahui berapa besar hubungan kesuaian dan prediksis kadar antibiotika profilaksis terhadap kejadian infeksi luka operasi.

\section{METODOLOGI}

\section{Rancangan Penelitian}

Penelitian ini bersifat observasional analitik dengan rancangan case control study. Pengambilan sampel dilakukan secara retrospektif pada bulan Mei-Juli 2018 di RSUP dr Sardjito, Yogyakarta.

\section{Subyek Penelitian}

Subyek penelitian adalah rekam medis pasien bedah obsgin. Sejumlah 21 pasien pada kelompok ILO dan 63 pasien pada kelompok tidak ILO. Kriteria Inklusi yang digunakan adalah rekam medis pasien bedah obsgin $>18$ tahun, mendapatkan antibiotik profilaksis, pasien yang mengalami infeksi luka operasi, pada kelompok ILO dan tidak mengalami infeksi luka operasi pada kelompok tidak ILO. Pasien yang infeksi sebelum dilakukan operasi dieksklusi dari penelitian ini.

\section{Penilaian Kesesuaian Antibiotik Profilaksis}

Penilaian kesesuain antibiotik profilaksis dilakukan berdasarkan PPAB RSUP Dr. Sardjito Yogyakarta. Sedangkan perhitungan prediksi kadar antibiotik profilaksis dalam darah. Tahap - tahap yang dilakukan dalam prediksis kadar adalah menghitung estimasi Kreatinin klirens pasien dengan formula Cockroft Gault (Cockroft and Gault, 1976):

Perempuan:

$$
\mathrm{CrCl}=\frac{0,85 \times(140-\text { usia (tahun) } x \text { Berat } \text { Badan }(\mathrm{kg})}{72+\text { Serum Kreatinin }\left(\frac{m g}{d l}\right)}
$$

Perhitungan selanjutnya menggunakan persamaan Bauer, 2008:

$$
\mathrm{Ct}=\left(\mathrm{D}_{\mathrm{L}} / \mathrm{Vd}\right) \cdot \mathrm{e}^{\mathrm{Ku}}
$$

Ct : kadar pada waktu tertentu; $\mathrm{D}_{\mathrm{L}}$ : dosis antibiotik profilaks; Vd : volume distribusi; K : tetapan eliminasi obat; $\mathrm{G}$ : interval pemberian obat

\section{Analisis Data}

Analisis data secara deskriptif dilakukan untuk mengetahui karakteristik pasien. Analisis statistik Chi-square digunakan untuk mengetahui hubungan kesesuaian dan prediksi antibiotik profilaksis terhadap kejadian ILO.

\section{HASIL DAN PEMBAHASAN}

Karakteristik pasien bedah obsgin terlihat pada tabel I. Pada penelitian ini usia $<60$ tahun lebih banyak mengalami ILO dikarenakan persentase sampel lebih banyak pada usia tersebut. Neumayer dkk., 2007 menunjukkan bahwa usia $>40$ tahun memiliki risiko ILO lebih tinggi dibandingkan $<40$ tahun. Hal ini juga sesuai dengan studi yang ditemukan oleh Bharatur dkk (2018), dimana usia wanita 36-50 
Tabel I. Karakteristik Pasien Obsgin di RSUP Dr. Sardjito, Yogyakarta

\begin{tabular}{|c|c|c|c|c|c|c|}
\hline \multirow{2}{*}{ Variabel } & \multirow{2}{*}{ Jumlah (n) } & \multicolumn{2}{|c|}{ ILO (n=21) } & \multicolumn{2}{|c|}{ Tidak ILO (n=63) } & \multirow[t]{2}{*}{ Pvalue } \\
\hline & & $\mathbf{n}$ & $\%$ & $\mathbf{n}$ & $\%$ & \\
\hline \multicolumn{7}{|l|}{ Usia } \\
\hline$\geq 60$ tahun & 22 & 7 & 31,8 & 15 & 68,2 & $0,39^{1}$ \\
\hline$<60$ tahun & 62 & 14 & 22,6 & 48 & 77,4 & \\
\hline \multicolumn{7}{|l|}{ BMI } \\
\hline Obesitas & 55 & 13 & 23,6 & 42 & 76,4 & $0,69^{1}$ \\
\hline Nonobesitas & 29 & 8 & 27,6 & 21 & 72,4 & \\
\hline \multicolumn{7}{|l|}{ Kadar gula darah } \\
\hline$\geq 200$ & 0 & 0 & 0 & 0 & 0 & - \\
\hline$<200$ & 84 & 21 & 25 & 63 & 75 & \\
\hline \multicolumn{7}{|l|}{ Albumin } \\
\hline Hipoalbumin & 20 & 5 & 25,0 & 15 & 75,0 & $1,0^{1}$ \\
\hline Normoalbumin & 64 & 16 & 25,0 & 48 & 75,0 & \\
\hline \multicolumn{7}{|l|}{ Kelas Operasi } \\
\hline Bersih Terkontaminasi & 44 & 10 & 22,7 & 34 & 77,3 & $0,61^{1}$ \\
\hline Bersih & 40 & 11 & 27,5 & 29 & 72,5 & \\
\hline \multicolumn{7}{|l|}{ Sifat Operasi } \\
\hline Emergensi & 9 & 2 & 9,5 & 7 & 11,1 & $1,3^{1}$ \\
\hline Elektif & 75 & 19 & 90,5 & 56 & 88,9 & \\
\hline \multicolumn{7}{|l|}{ Perdarahan } \\
\hline$\geq 1500 \mathrm{ml}$ & 6 & 1 & 16,7 & 5 & 83,3 & $1,00^{2}$ \\
\hline$<1500 \mathrm{ml}$ & 78 & 20 & 25,6 & 58 & 74,4 & \\
\hline \multicolumn{7}{|l|}{ Length of stay } \\
\hline$>8$ hari & 41 & 13 & 31,7 & 28 & 68,3 & $0,16^{1}$ \\
\hline$\leq 8$ hari & 43 & 8 & 18,6 & 35 & 81,4 & \\
\hline \multicolumn{7}{|l|}{ Lama rawat pre operasi } \\
\hline$>3$ hari & 38 & 9 & 23,7 & 29 & 76,3 & $0,80^{1}$ \\
\hline$\leq 3$ hari & 46 & 12 & 26,1 & 34 & 73,9 & \\
\hline \multicolumn{7}{|l|}{ Komorbid } \\
\hline$\geq 2$ komorbid & 6 & 3 & 50 & 3 & 50 & $0,91^{3}$ \\
\hline$<2$ komorbid & 21 & 2 & 9,5 & 19 & 90,5 & \\
\hline Tidak ada komorbid & 57 & 16 & 28,1 & 41 & 71,9 & \\
\hline
\end{tabular}

tahun memiliki risiko 1,3 kali lebih tinggi dibantdingkan usia $\leq 35$ tahun, dan wanita dengan usia > 50 tahun memiliki risiko lebih tinggi mengalami ILO.

Sebanyak 13 pasien dengan BMI obesitas yang mengalami ILO $(23,6 \%)$, dan 8 pasien dengan status BMI nonobesitas yang mengalami ILO (27,6\%). Peningkatan angka kejadian ILO pada obesitas telah diteliti sebelumnya pada operasi jantung, tulang dan sesar dimana terdapat hubungan yang bermakna antara komplikasi bedah dengan peningkatan BMI $(\mathrm{P}<0,001)$ dibandingkan BMI normal(Khavanin dkk., 2013).

Pada penelitian ini terdapat 3 pasien ILO dengan komorbid diabetes mellitus dan 4 pasien tidak ILO dengan komorbid diabetes mellitus.
Namun seluruh pasien baik dengan komorbid maupun tidak dengan komorbid diabetes mellitus memiliki kadar gula darah preoperasi <200 mg/dL. Pada studi Al-Niaimi dkk., 2015 managemen kadar glukosa yang ketat dapat menurunkan ILO pada pasien diabetes. Namun, berdasarkan review Cochrane (2009) dalam membandingkan glikemik dengan kontrol yang ketat dan konvensional (kadar gula darah $<200$ $\mathrm{mg} / \mathrm{dL}$ ) tidak ditemukan perbedaan yang signifikan dalam mencegah terjadinya ILO.

Kadar albumin menjadi salah satu kriteria yang dapat berpengaruh pada kejadian infeksi luka operasi sesuai dengan faktor risiko yang disebutkan dalam PPAB RSUP Dr. Sardjito. Albumin dikatakan normal apabila nilainya $\geq 3,4$ $\mathrm{g} / \mathrm{dL}$. Pada penelitian ini terdapat 16 pasien 
normoalbumin (25\%) dan 5 pasien hipoalbumin (25\%) pada kelompok ILO, sedangkan kelompok tidak ILO terdapat 48 pasien (75\%) normoalbumin dan 15 pasien (75\%) hipoalbumin.

Risiko kejadian infeksi luka operasi tergantung pada masing-masing kelas operasi. Operasi bersih memiliki kemungkinan timbulnya infeksi adalah 2-4\%, sedangkan operasi bersih terkontaminasi memiliki risiko 515\% (Mayhall Clasification). Pada penelitian ini terdapat 11 pasien $(27,5 \%)$ dengan kelas operasi bersih dan 10 pasien $(22,7 \%)$ bersih terkontaminasi pada kelompok ILO. Sedangkan pada kelompok tidak ILO terdapat 29 pasien (72,5\%) dengan kelas operasi bersih dan 24 pasien $(77,3 \%)$ dengan kelas operasi bersih terkontaminasi.

Pada sifat operasi ini terdapat 19 pasien $(23,4 \%)$ operasi elektif dan 2 pasien $(42,9 \%)$ operasi emergensi pada kelompok ILO. Sedangkan pada kelompok tidak ILO terdapat 56 pasien $(76,6 \%)$ operasi elektif dan 7 pasien $(57,1 \%)$ operasi emergensi yang tidak menglami infeksi luka operasi. Pasien yang menjalani operasi emergensi (cito) terjadi pada pasien sesar atas kasus perdarahan dan preeklamsia berat (PEB). Namun pada penelitian ini ILO lebih tinggi pada pasien yang menjalani operasi elektif kemungkinan karena persentase jenis operasi elektif jauh lebih besar dari jenis operasi emergensi (Sáez-Castillo dkk., 2010).

Perdarahan yang dialami selama operasi menjadi pertimbangan dalam memberikan dosis ulangan untuk mencegah terjadinya ILO. Dalam penelitian ini 1 pasien $(16,7 \%)$ yang mengalami ILO dengan jumlah perdarahan $>1500 \mathrm{ml}$ dan 20 pasien lainnya $\leq 1500 \mathrm{ml}$ $(25,6 \%)$. Sedangkan pasien yang tidak mengalami ILO dengan jumlah perdarahan $>1500 \mathrm{ml}$ sebesar 5 pasien $(83,3 \%)$ dan 58 pasien dengan perdarahan $\leq 1500 \mathrm{ml}(74,4 \%)$. Menurut Tuomi., dkk (2015) dalam studi kohort retrospektif pada histerektomi menyebutkan bahwa tidak terdapat perbedaan signifikan antara yang mengalami perdarahan $>350 \mathrm{ml}$ apda operasi dengan kejadian infksi luka operasi $(p 0,945)$.

Lama rawat di rumah sakit baik sebelum maupun sesudah operasi dapat berpengaruh terhadap infeksi yang disebabkan oleh kontaminasi bakteri rumah sakit. Berdasarkan penelitian Pathak dkk., (2017) lama rawat post operasi antara 7-14 hari menunjukkan nilai yang signifikan secara statistik sebagai penyebab infeksi luka operasi ( $p 0,001$; OR 2,34; 95\%CI 1,43-3,84). Sedangkan pada pasien dengan rawat inap $>14$ hari memiliki risiko 7,5 kali mengalami infeksi luka operasi $(p<0,005$; $95 \%$ CI 4,07-13,84). Lama rawat berdasarkan nilai median pada penelitian ini adalah 8 hari. Pasien dengan lama rawat $>8$ hari mengalami ILO sebanyak 13 pasien $(31,7 \%)$ dan 28 pasien $(68,3 \%)$ tidak mengalami ILO. Sedangkan pasien dengan lama rawat $\leq 8$ hari sebanyak 8 pasien $(18,6 \%)$ yang mengalami ILO dan sebanyak 35 pasien $(81,4 \%)$ tidak mengalami infeksi luka operasi. Meskipun secara statistik tidak bermakna namun persentase kejadian ILO pada pasien yang dirawat $>8$ hari memiliki kejadian infeksi luka operasi lebih besar dibandingkan dengan rawat inap $\leq 8$ hari.

Lama rawat inap sebelum operasi pada penelitian ini terbagi atas dua yaitu, $>3$ hari dan $\leq 3$ hari. Pasien dengan lama rawat inap pre operasi $>3$ hari sebanyak 9 pasien $(23,7 \%)$ mengalami ILO dan sebanyak 29 pasien $(76,3 \%)$ tidak mengalami ILO. Sedangkan pada lama rawat inap pre operasi $\leq 3$ hari terdapat 12 pasien $(26,1 \%)$ yang mengalami ILO dan 34 pasien $(73,9 \%)$ tidak mengalami ILO. Secara statistik dan persentase tidak terdapat perbedaan yang signifikan antara keduanya. Hal ini sesuai dengan penelitian sebelumnya yang dilakukan oleh Mujagic dkk (2018) dengan analisis multivariat bahwa tidak adanya hubungan yang signifikan antara lama rawat inap sebelum operasi dengan kejadian ILO, namun terdapat hubungan lama rawat inap paska operasi dengan kejadian ILO.

Pada penelitian ini terbagi atas 2 kategori komorbid yaitu $\geq 2$ komorbid dan $<2$ komorbid. Komorbid yang terdapat dalam sampel penlitian ini adalah hipertensi, diabetes mellitus (DM), preeklamsia, ketuban pecah dini. Kategori $\geq 2$ komorbid adalah hipertensi dan DM. Pasien dengan komorbid $\geq 2$ sebesar 3 pasien dan $<2$ sebesar 2 pasien pada ILO, sedangkan pada kelompok tidak ILO komorbid $\geq 2$ sebanyak 3 pasien dan $<2$ sebanyak 19 pasien. Studi yang dilakukan Martin dkk (2016) dalam mecari hubungan diabetes mellitus dengan mengendalikan BMI menunjukkan bahwa terdapat hubungan yang signifikan terhadap kejadian ILO (Vallejo dkk., 2017) dan (Martin dkk., 2016). Namun, pada penelitian ini tidak dapat dilakukan penilaian terhadap faktor risiko 
Tabel II. Hubungan Kesesuaian Antibiotika Profilaksis dengan Kejadian ILO

\begin{tabular}{|c|c|c|c|c|c|c|c|}
\hline \multirow[t]{2}{*}{ Variable } & \multicolumn{2}{|c|}{$\begin{array}{c}\text { ILO } \\
(n=21)\end{array}$} & \multicolumn{2}{|c|}{$\begin{array}{c}\text { Tidak ILO } \\
(n=63)\end{array}$} & \multirow[t]{2}{*}{$\mathbf{O R}$} & \multirow[t]{2}{*}{$95 \% \mathrm{CI}$} & \multirow{2}{*}{$\begin{array}{c}P \\
\text { Value }\end{array}$} \\
\hline & $\mathbf{n}$ & $\%$ & $\mathbf{n}$ & $\%$ & & & \\
\hline \multicolumn{8}{|c|}{ Jenis Antibiotik } \\
\hline Tidak Sesuai & 1 & 50 & 1 & 50 & 3,1 & $0,18-5,87$ & $0,44^{2}$ \\
\hline Sesuai & 20 & 24,4 & 62 & 75,6 & & & \\
\hline \multicolumn{8}{|l|}{ Dosis } \\
\hline Tidak Sesuai & 21 & 25 & 63 & 75 & - & - & - \\
\hline Sesuai & - & - & - & - & & & \\
\hline \multicolumn{8}{|c|}{ Waktu Pemberian } \\
\hline Tidak Sesuai & 13 & 30,2 & 30 & 69,8 & 1,79 & $0,65-4,91$ & $0,25^{1}$ \\
\hline Sesuai & 8 & 19,5 & 33 & 80,5 & & & \\
\hline \multicolumn{8}{|l|}{ Rute } \\
\hline Tidak Sesuai & - & - & - & - & - & - & - \\
\hline Sesuai & 21 & 25 & 63 & 75 & & & \\
\hline \multicolumn{8}{|l|}{ Interval } \\
\hline Tidak Sesuai & 7 & 31,8 & 15 & 68,2 & 1,6 & $0,55-4,69$ & $0,39^{1}$ \\
\hline Sesuai & 14 & 22,6 & 48 & 77,4 & & & \\
\hline \multicolumn{7}{|c|}{ Tingkat Kesesuaian } & 2 \\
\hline 3 & 5 & 41,7 & 7 & 58,3 & 2,1 & $0,55-7,91$ & $0,30^{1}$ \\
\hline 4 & 11 & 25,6 & 32 & 74,4 & & & \\
\hline & 5 & 17,6 & 24 & 82,8 & - & - & - \\
\hline
\end{tabular}

dengan komorbid tersebut karena keterbatasan sampel.

Skor ASA 2 merupakan skor ASA pada seluruh pasien pada studi ini. Penelitian tentang faktor risiko infeksi luka operasi pasca sectio caesarea pernah dilakukan oleh olsen (2008) dari penelitian tersebut dapat disimpulkan bahwa faktor risiko ILO meningkat pada pasien dengan penyakit sistemik berat (skor ASA $\geq 3$ ).

Hubungan Kesesuaian Antibiotik Profilaksis Jenis antibiotik profilaksis

Kesesuaian jenis antibiotik dengan PPAB RSUP Dr. Sardjito pada studi ini ditemukan sebanyak 20 pasien $(24,4 \%)$ sesuai dan 1 pasien (50\%) tidak sesuai pada kelompok ILO. Sedangkan pada kelompok tidak ILO ditemukan 62 pasien $(75,6 \%)$ sesuai dan 1 pasien (50\%) tidak sesuai. Jenis antibiotik profilaksis yang sesuai dengan pedoman adalah sefalosporin generasi 1 (cefazolin) dan generasi 2 (cefuroxime). Secara statistik tidak terdapat hubungan yang signifikan antara kesesuaian jenis antibiotik terhadap kejadian ILO $(p>0,05)$. Hal ini dapat terjadi karena kurangnya sampel dalam penelitian ini.
Dosis antibiotik profilaksis

Dosis yang diberikan pada kelompok ILO 25\% dan kelompok tidak ILO 75\% tidak sesuai dengan pedoman. Berdasarkan pedoman PPAB RSUP Dr. Sardjito dosis antibiotika profilaksis yang diberikan sebelum insisi adalah 2 gram. Dosis antibiotik yang digunakan sebagai pencegahan infeksi pada bedah harus lebih besar daripada dosis terapi. Pemberian dosis 2 gram yang sesuai dengan pedoman merupakan dosis yang dapat diberikan pada pasien dengan BMI normal, jika pasien memiliki berat badan $\geq 120 \mathrm{~kg}$ maka dosis yang diberikan adalah 3 gram. Pada studi ini secara statistik tidak terdapat hubungan kesesuaian dosis antibiotik profilaksis dengan kejadian ILO. Namun pada penelitian ini penggunaan antibiotik profilaksis sebesar 1 gram tidak menunjukkan hubungan yang signfikan terhadap kejadian ILO dimungkinkan karena sampel yang kecil. Berdasarkan data dilapangan kesalahan dosis antibiotik dikarenakan dosis yang lebih kecil dari seharusnya, seperti dosis cefazolin yang diberikan 1 gram. Hal ini dikhawatirkan dapat menimbulkan kondisi subterapetik antibiotik sehingga meningkattkan risiko terjadinya infeksi. 
Waktu Pemberian

Delapan pasien $(19,5 \%)$ dengan waktu pemberian yang sesuai mengalami infeksi luka operasi, sedangkan tiga belas pasien $(30,2 \%)$ mengalami infeksi luka operasi dengan waktu pemberian yang tidak sesuai (OR 1,79, 95\% CI $0,20-1,53$, p $>0,05$ ). Waktu pemberian yang sesuai pada studi ini merujuk pada pedoman PPAB RSUP Dr. Sardjito yaitu 30-60 menit. Secara statistik tidak terdapat hubungan antara waktu pemberian yang sesuai dan yang tidak sesuai. Namun secara persentase pasien yang mengalami ILO dengan waktu pmberian yang tidak sesuai terlihat lebih tinggi dibandingan pasien yang ILO dengan waktu pemberian yang sesuai.

\section{Rute pemberian}

Rute pemberian dilakukan secara intravena pada seluruh pasien (100\%). Pemilihan rute pemberian dapat berpengaruh pada efektivitas dari antibiotik profilaksis jika waktu mulai operasi tidak dilakukan penyesuaian dengan rute pemberian. Rute pemberiana secara intravena dapat dilakukan dengan cara bolus dan drip (bolus lambat). Kedua hal ini akan memiliki waktu mulai insisi yang berbeda. Berdasarkan Mangram dkk., 1999, pemberian antibiotika secara intravena menghasilkan konsentrasi antibiotika paling adekuat pada jaringan yang dibutuhkan meskipun terdapat pula rute lain seperti oral, topikal, dan intramuskular.

Interval

Selain rute pemberian, interval dalam pemberian antibiotik tidak kalah penting. Kesesuian interval pemberian antibiotik terdapat 14 pasien $(22,6 \%)$ sesuai dan 7 pasien $(31,8 \%)$ tidak sesuai pada kelompok ILO, sedangkan pada kelompok tidak ILO terdapat 48 pasien $(77,4 \%)$ sesuai dan 15 pasien $(68,2 \%)$ tidak sesuai. Kesesuaian interval pemberian ini adalah lama pemberian antibiotik profilaksis pasca operasi. Dikatakan sesuai apabila pemberian $\leq 24$ jam dan tidak sesuai apabila $>$ 24 jam. Peningkatan risiko resistensi antimikroba yang diperoleh (cephalosporinresistant, Enterobacteriaceae, dan vancomisinresistant Enterococci) yang dikaitkan dengan lama pemberian antibiotika profilaksis dibandingkan dengan pemberian jangka panjang (OR 1,6; 95\%CI 1,1-2,6). Selain itu, beberapa penelitian menyebutkan bahwa tidak ada manfaat jika lama pemberian antibiotika profilaksis diperpanjang (SIGN, 2008). Hal ini dapat dilihat pada persentase jumlah pasien ILO dengan ketidaksesuaian lebih besar $(31,8 \%)$ dibandingkan pasien ILO yang sesuai. Artinya pemberian $>24$ jam dengan tujuan pencegahan infeksi luka operasi belum menunjukkan manfaat yang lebih besar dibandingkan $\leq 24$ jam.

\section{Tingkat kesesuaian antibiotik profilaksis}

Penilaian tingkat kesesuaian antibiotik profilaksis pada studi ini disesuaikan dengan pedoman PPAB RSUP Dr. Sardjito. Pada kelompok ILO terdapat 5 pasien $(41,7 \%)$ yang memiliki dua kesesuain dengan pedoman dan 7 pasien $(58,3 \%)$ pada kelompok tidak ILO. Pasien yang memiliki 3 kesesuaian sebanyak 11 pasien (25,6\%) pada kelompok ILO dan $32(74,4 \%)$ pada kelompok tidak ILO, dan pasien yang memiliki 4 kesesuaian sebanyak 5 pasien $(17,6 \%)$ pada kelompok ILO dan $24(82,8 \%)$ pada kelompok tidak ILO. Secara statistik tidak terdapat hubungan antara tingkat kesesuaian antibiotik profilaksis terhadap infeksi luka operasi. Namun hasil ini menunjukkan semakin tinggi tingkat kepatuhan (kesesuaian terhadap pedoman) dalam penggunaan antibiotik profilaksis akan dapat menurunkan tingkat infeksi luka operasi.

\section{Hubungan Prediksi Kadar Antibiotik Profilaksis}

Antibiotik profilaksis yang adekuat merupakan hal yang penting dalam upaya pencegahan infeksi luka operasi. Untuk memperoleh efek yang adekuat, antibiotik harus tetap berada pada tempat ikatannya untuk waktu yang cukup memadai. Kadar hambat minimum (KHM) merupakan gambaran jumlah minimal obat yang diperlukan untuk menghambat pertumbuhan bakteri. Pada penelitian ini terdapat dua antibiotik profilakasis yang digunakan yaitu cefazoin dan cefotaxime. Kedua obat ini memiliki kadar hambat minum yang sama yaitu $8 \mathrm{mg} / \mathrm{l}$. Konsentrasi antibiotik profilaksis pada ILO dan tidak ILO dapat dilihat pada tabel III.

Hasil perhitungan kadar antibiotik profilaksis pasien pada saat insisi berada diatas kadar hambat minimum. Sedangkan perhitungan kadar pada saat operasi selesai terdapat 3 pasien $(3,6 \%)$ dengan kadar terendah 4,30 mg/L. Kadar hambat minumum dari cefazolin dan cefotaxime berdasarkan 
Tabel III. Konsentrasi Kadar Hambat Minimum Antibiotik Profilaksis Pada ILO Dan Tidak ILO Saat Insisi Dan Saat Operasi Selesai

\begin{tabular}{ccccc}
\hline \multirow{2}{*}{$\begin{array}{c}\text { Konsentrasi } \\
\text { (mg/L) }\end{array}$} & Saat insisi & $\begin{array}{c}\text { Saat operasi } \\
\text { selesai }\end{array}$ & Saat insisi & $\begin{array}{c}\text { Saat operasi } \\
\text { selesai }\end{array}$ \\
\cline { 2 - 5 } & 77,80 & 26,02 & 76,23 & 29,75 \\
X & 22,37 & 12,07 & 19,24 & 10,70 \\
SD & 24,34 & 4,30 & 30,00 & 8,42 \\
Min & 134,34 & 44,99 & 119,39 & 54,78 \\
Max & & &
\end{tabular}

Tabel IV. Hubungan Konsentrasi Kadar Hambat Minimum Antibiotik Profilaksis Pada ILO Saat Operasi Selesai

\begin{tabular}{|c|c|c|c|c|c|c|c|}
\hline \multirow{2}{*}{ Variabel } & \multicolumn{2}{|c|}{ ILO } & \multicolumn{2}{|c|}{ Tidak ILO } & \multirow{2}{*}{$\mathbf{R R}$} & \multirow{2}{*}{$95 \%$ CI } & \multirow{2}{*}{$\begin{array}{c}P \\
\text { value }\end{array}$} \\
\hline & n & $\%$ & n & $\%$ & & & \\
\hline$<$ KHM & 3 & 100 & 0 & 0 & 4,5 & $2,99-6,76$ & 0,01 \\
\hline$\geq \mathrm{KHM}$ & 18 & 22,2 & 63 & 77,8 & & & \\
\hline t KHM & & & & & & & \\
\hline$<6$ jam & 16 & 30,2 & 37 & 69,8 & 2,25 & $0,73-6,91$ & 0,19 \\
\hline$\geq 6$ jam & 5 & 16,1 & 26 & 83,9 & & & \\
\hline
\end{tabular}

literatur adalah $8 \mathrm{mg} / \mathrm{L}$ (Lanckohr dkk., 2016 dan Elkomy dkk., 2014). Berdasarkan studi yang dilakukan Grujic dkk (2010) yang melakukan uji konsentrasi cefazolin 2 gram sebagai antibiotik profilaksis bedah sesar, ditemukan bahwa terjadi penurunan kadar antibiotik setelah 6 jam menjadi 24,8 mg/L meskipun kadar ini masih berada di atas KHM.

Prediksi kadar antibiotik profilaksis terhadap kejadian infeksi luka operasi dilakukan pada saat insisi dan setelah operasi selesai. Kadar obat setelah injeksi intravena bolus sebagai dosis awal dapat dihitung menggunakan rumus berikut:

$$
C t=\left(D_{L} / V d\right) \cdot e^{-K \tau}
$$

Berdasarkan rumus diatas, $\mathrm{D}_{\mathrm{L}}$ merupakan dosis dari cefazolin maupun cefotaxime. Dosis cefazolin maupun cefotaxime yang diberikan adalah 1 gram. Sedangkan volume distribusi (Vd) dari cefazolin adalah 0,13-1,22 l/kg, waktu eliminasi dari cefazolin adalah 90-150 menit. Sedangkan cefotaxime memiliki volume distribusi 0,15-0,55 l/kg dengan waktu eliminasi 54-68 menit. Perhitungan pada volume distribusi setiap pasien berbeda tergantung klirens dan berat badan. Prediksi kadar antibiotik profilaksis terhadap ILO dapat dilihat pada tabel IV.

Berdasarkan hasil prediksi kadar saat insisi telah memenuhi standar KHM sedangkan saat operasi selesai terdapat tiga pasien yang belum memenuhi KHM. Kejadian infeksi luka operasi pada kadar antibiotik diatas KHM terdapat 18 pasien $(22,2 \%)$ dan 3 pasien (100\%) pada kelompok ILO dan 63 pasien (77,8\%) pada kelompok tidak ILO. Secara statistik kadar antibiotik profilaksis yang berada dibawah KHM signifikan meningkatkan ILO dengan nilai $\mathrm{p}<0,05$ (RR 4,5; 95\% CI 2,996,76).

Empat studi farmakokinetik menyebutkan bahwa pemberian cefazolin 2 gram tidak cukup adekuat pada pasien obesitas yang menjalani operasi sesar karena konsentrasi obat berada dibawah kadar hambat minimum sehingga dapat meningkatkan risiko infeksi luka operasi (Hussain dkk., 2018). Berdasarkan studi farmakokinetik (Elkomy dkk., 2014) kadar cefazolin 2 gram yang diberikan 60 menit sebelum insisi dapat berada diatas kadar target (42\%). Asumsi operasi berjalan selama 1 jam, maka setiap 2 jam harus diberikan cefazolin kembali dengan dosis 2 gram untuk mencapai target $>42 \%$. Tiga pasien yang mengalami infeksi luka operasi dalam studi memiliki kadar dibawah KHM. Hal ini dapat terjadi karena dosis yang diberikan tidak cukup adekuat dengan dosis 1 gram dan durasi operasi pada 2 pasien diantaranya $>6$ jam sedangkan 1 pasien $>2$ jam.

Waktu obat berada dalam kadar hambat minimum setiap pasien berbeda-beda. 
Pada penelitian ini meskipun 18 pasien yang memiliki kadar diatas KHM tetap mengalami infeksi luka operasi. Kondisi seperti ini dapat disebabkan oleh beberapa hal yaitu pemberian obat intravena drip (dalam penelitian ini diasumsikan semua pemberian intravena bolus karena belum ada keterangan pemberian secara intravena drip atau bolus), dosis tidak cukup adekuat, sensitivitas bakteri yang meningkat. Dikatakan susceptible apabila kadar antibiotik $\leq 8 \mathrm{mg} / \mathrm{L}$, intermediate $16 \mathrm{mg} / \mathrm{L}$, dan resistant $\geq 32 \mathrm{mg} / \mathrm{L}$ (Grujic dkk., 2010). Berdasarkan teori ini artinya ketika antibiotik profilaksis telah berada diatas KHM $8 \mathrm{mg} / \mathrm{L}$ namun masih mengalami ILO dapat dimungkinkan bakteri tersebut membutuhkan dosis yang adekuat untuk mencapai kadar hambat minimum diatas misal intermediate ataupun resistant.

\section{KESIMPULAN}

Hubungan kesesuaian antibiotika profilaksis dengan kejadian infeksi luka operasi secara statistik tidak bermakna $(p>0,05)$, namun semakin rendah tingkat kepatuhan terhadap pedoman maka semakin besar pula tingkat infeksi luka operasi yang ditimbulkan $(41,7 \%)$. Terdapat hubungan antara prediksi kadar antibiotika profilaksis terhadap kejadian infeksi luka operasi pada pasien bedah obsgin dengan kadar antibiotika profilaksis dibawah kadar hambat minimum pada saat operasi selesai $(p<0,05)$.

\section{UCAPAN TERIMA KASIH}

Penulis mengucapkan terimakasih kepada RSUP Dr. Sardjito atas kerjasama dalam pengambilan data pada penelitian ini.

\section{DAFTAR PUSTAKA}

ACOG Practice Bulletin No. 195: Prevention of Infection After Gynecologic Procedures, 2018. . Obstetrics and Gynecology, 131: e172-e189.

Al-Niaimi, A.N., Ahmed, M., Burish, N., Chackmakchy, S.A., Seo, S., Rose, S., dkk., 2015. Intensive postoperative glucose control reduces the surgical site infection rates in gynecologic oncology patients. Gynecologic Oncology, 136: 71-76.

Bharatnur, S. dan Agarwal, V., 2018. Surgical site infection among gynecological group: risk factors and postoperative effect. International Journal of Reproduction,
Contraception, Obstetrics and Gynecology, 7: 966.

Bratzler, D.W., Dellinger, E.P., Olsen, K.M., Perl, T.M., Auwaerter, P.G., Bolon, M.K., dkk., 2013. Clinical practice guidelines for antimicrobial prophylaxis in surgery. American Journal of Health-System Pharmacy, 70: 195-283.

Cockcroft, D. W., and M. H. Gault, 1976, Prediction of Creatinine Clearance from Serum Creatinine, Nephron 16, no. 1 (1976): 31-41.

Elkomy, M.H., Sultan, P., Drover, D.R., Epshtein, E., Galinkin, J.L., dan Carvalho, B., 2014. Pharmacokinetics of Prophylactic Cefazolin in Parturients Undergoing Cesarean Delivery. Antimicrobial Agents and Chemotherapy, 58: 3504-3513.

Grujic, Z., Popovic, J., Bogavac, M., dan Grujic, I., 2010. Preoperative administration of cephalosporins for elective caesarean delivery. Srpski arhiv za celokupno lekarstvo, 138: 600-603.

Khavanin, N., Lovecchio, F.C., Hanwright, P.J., Brill, E., Milad, M., Bilimoria, K.Y., dkk., 2013. The influence of BMI on perioperative morbidity following abdominal hysterectomy. American Journal of Obstetrics and Gynecology, 208: 449.e1-449.e6.

Koch, C.G., Li, L., Hixson, E., Tang, A., Gordon, S., Longworth, D., dkk., 2013. Is It Time to Refine? An Exploration and Simulation of Optimal Antibiotic Timing in General Surgery. Journal of the American College of Surgeons, 217: 628-635.

Mangram, A.J., Horan, T.C., Pearson, M.L., Silver, L.C., dan Jarvis, W.R., 1999. GUIDELINE FOR PREVENTION OF SURGICAL SITE INFECTION, 1999 20: 32.

Martin, E.T., Kaye, K.S., Knott, C., Nguyen, H., Santarossa, M., Evans, R., dkk., 2016. Diabetes and Risk of Surgical Site Infection: A Systematic Review and Metaanalysis. Infection Control \& Hospital Epidemiology, 37: 88-99.

Neumayer, L., Hosokawa, P., Itani, K., El-Tamer, M., Henderson, W.G., dan Khuri, S.F., 2007. Multivariable Predictors of Postoperative Surgical Site Infection after General and Vascular Surgery: Results from the Patient Safety in Surgery Study. Journal of the American College of Surgeons, 204: 1178-1187. 
Sáez-Castillo, A.J., Olmo-Jiménez, M.J., Pérez Sánchez, J.M., Negrín Hernández, M.Á., Arcos-Navarro, Á., dan Díaz-Oller, J., 2010. Bayesian Analysis of Nosocomial Infection Risk and Length of Stay in a Department of General and Digestive Surgery. Value in Health, 13: 431-439.
Vallejo, M.C., Attaallah, A.F., Shapiro, R.E., Elzamzamy, O.M., Mueller, M.G., dan Eller, W.S., 2017. Independent risk factors for surgical site infection after cesarean delivery in a rural tertiary care medical center. Journal of Anesthesia, 31: 120126. 